\title{
Comparison of bacterial dynamics in tidal creeks of the lower Delmarva Peninsula, Virginia, USA
}

\author{
Katherine M. MacMillin, Linda K. Blum*, Aaron L. Mills \\ Laboratory of Microbial Ecology, Department of Environmental Sciences, University of Virginia, Charlottesville, \\ Virginia 22903, USA
}

\begin{abstract}
Bacterial biomass, abundance, and productivity were greater in 3 tidal marsh creeks on the Chesapeake Bay side of the lower Delmarva Peninsula than in nearby creeks of the seaside coastal lagoon complex (biomass: 462 and $71 \mathrm{ng} \mathrm{C} \mathrm{ml}^{-1}$; abundance: $12 \times 10^{6}$ and $3.8 \times 10^{6}$ cells ml $^{-1}$; produc-

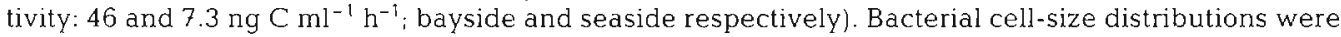
also significantly different between the seaside and bayside creeks, with a larger proportion of smaller cells dominating samples from the seaside creeks. Bayside and seaside concentrations of total suspended solids (TSS) and dissolved organic carbon (DOC) were similar (approximately $49 \mathrm{mg} \mathrm{l}^{-1}$ TSS and $3.5 \mathrm{mg} \mathrm{l}^{-1}$ DOC). The amount of organic matter (OM) and chlorophyll a was higher in the bayside creeks, while inorganic $N$ and $P$ concentrations were higher in the seaside creeks (OM: 9.0 and $3.4 \mathrm{mg}$ $1^{-1}$; chlorophyll a: 6.0 and $4.1 \mathrm{~g} \mathrm{l}^{-1} ; \mathrm{PO}_{4}{ }^{3-}: 0.2$ and $1.2 \mu \mathrm{M}_{;} \mathrm{NH}_{4}{ }^{+}: 0.6$ and $1.2 \mu \mathrm{M}_{i}$ bayside and seaside respectively). The high inorganic nutrient pools combined with the low levels of bacterial productivity suggest that bacterial production is not limited by $\mathrm{N}$ or $\mathrm{P}$ in the seaside creeks and that the amount of carbon moving through the bacterial loop is much less than on the bayside. In fact, DOC turnover times were much longer for the seaside ( $22 \mathrm{~d}$ ) than for the bayside $(6 \mathrm{~d})$. Reasons for the observed differences in bacterial dynamics for the bay and seasides are not known specifically, but may be related to differences in the source $o$ : the DOC (marsh grass vs phytoplankton), grazing on the bacterial cells, or bacterial community structure.
\end{abstract}

\section{INTRODUCTION}

In aquatic systems, bacteria: abundance, biomass, and productivity are influenced by a number of factors including substrate availability (Morita 1982, Wright 1984), primary production (Cole et al. 1988), and bacterivory (Wright \& Coffin 1984a, b, Güde 1989, Gonzalez et al. 1990). Bacterial and primary production in Chesapeake Bay (USA) have been extensively studied and much progress has been made in understanding the factors which control both bacterial and primary production. The highly eutrophic waters of the Chesapeake Bay support high rates of phytoplankton and bacterial production (Jonas 1992, Malone 1992). Phytoplankton production is most often limited by nutrients (Boynton et al. 1982) or light (Williams 1972) and bacterial production is usually most directly dependent on dissolved organic matter (Jonas \& Tuttle 1990). The nearby coastal lagoon complex (CLC) of the

- Addressee for correspondence eastern shore of Virginia has not been subject to the same scrutiny. However, preliminary surveys of inorganic nutrients, suspended solids, and microbiological characteristics suggest that the creeks on the bayside of the Delmarva Peninsula differ substantially from those on the seaside, even though they are separated by only a few km (Mills et al. 1990).

Coastal lagoon complexes represent a different, but very important, type of land-sea interface. The coastal lagoons of the Delmarva Peninsula have counterparts on all continents except Antarctica. The entire east and Gulf coast of the U.S. is bordered by barrier islands and lagoons, and CLC systems account for a significant part of the west and Alaskan coasts as well. These systems represent a quantitatively important class of land-margin zones that accounts for $13 \%$ of the total coastal area of the globe (Nixon 1982), and the productivity of coastal lagoons appears to be substantial (Vannucci 1969, Nixon 1982). However, the geographic importance of CLCs is not reflected in the amount of research attention paid to them (Day et al. 1989). 
Marsh creeks on the bayside and seaside of the lower Delmarva Peninsula are separated by less than $7 \mathrm{~km}$, and therefore offer the unique opportunity for comparative study of estuarine and coastal lagoon systems without major differences in regional or local climate, land-use patterns, or tidal amplitude (Fig. 1). The purpose of the research reported here was to determine if observed differences in microbial abundance and pool sizes of inorganic nutrient standing stocks were reflected in microbial transformations of carbon in estuarine and coastal lagoon marsh creeks. The approach used to address this question was to examine bayside and seaside marsh creek water for differences in bacterial abundance, biomass, and productivity, as well as aspects of water quality including dissolved organic carbon (DOC), total suspended solids (TSS), ash-free dry weight of suspended solids (i.e. organic matter content), and inorganic nutrients. Despite higher inorganic nutrient concentrations in the seaside creeks, bacteria were more abundant and had a greater biomass in the bayside creeks. These differences may be related to differences in the source (quality) of DOC, although grazing upon the bacteria or bacterial community structure may also be important. Clearly the seaside and bayside marsh creeks of the lower Delmarva peninsula differ in the bacterial metabolism of organic carbon.

\section{METHODS AND MATERIALS}

Site description. This study was conducted in 6 tidal marsh creeks on the eastern shore of Virginia (Fig. 1). Three of the creeks sampled, Nassawadox, Hungars, and Cherrystone, are on the Chesapeake Bay side (bayside) of the Delmarva Peninsula. Greens, Phillips, and Box Tree Creeks are on the seaside of the peninsula. Two surveys of each of the 6 creeks were conducted, one between June 20 and 22, 1991, and another between July 17 and 19, 1991. For each survey, 2 creeks were sampled per day: one on the bayside and one on the seaside of the peninsula. Samples were collected as close to high tide as possible and between 14:00 and 18:00 $\mathrm{h}$ to insure that the conditions were as similar as possible with respect to the tidal stage and light regime.

Although the creeks on the bayside and seaside are geographically close together, they differ significantly in terms of their morphology (Table 1). The seaside creeks are located within extensive marshes. These marshes are separated from the Atlantic Ocean by barrier islands and a wide, open, shallow lagoon. The channels of the creeks are deep and narrow. The creeks and marshes are routinely flooded with seawater. In contrast, the tidal creeks on the bayside are much wider and shallower, with water from Chesapeake Bay flooding directly into the creeks. The banks of the bayside creeks contain fringe marshes and samples were collected as closely as possible to those marshes.

Within each creek, an upper and a lower creek location were sampled. The lower creek locations were at the mouth of each creek, while the upper creek locations were as far upstream as could be reached by boat (approximately $0.5 \mathrm{~m}$ deep) at high tide. Triplicate water samples were collected from the surface at every station. Samples were collected for determination of bacterial abundance and productivity. Chlorophyll a

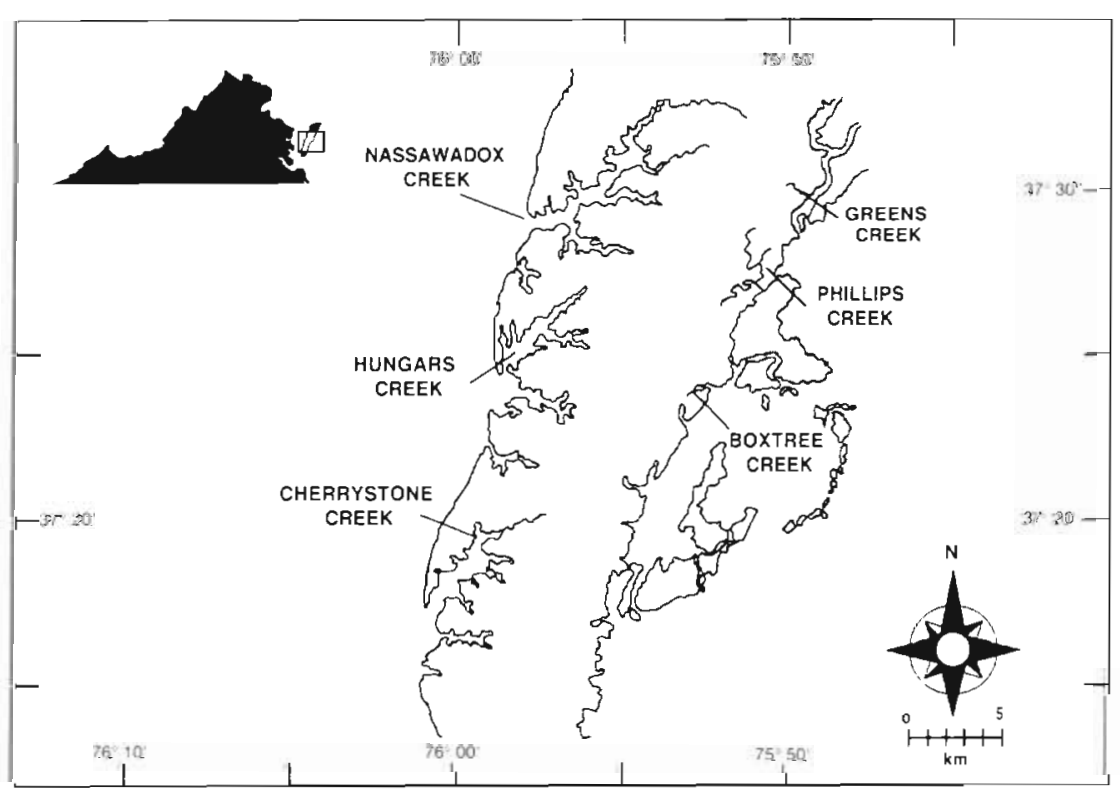

Fig. 1 The lower Delmarva Peninsula with the location of the Chesapeake Bay and coastal lagoon complex marsh creeks indicated. Inset shows the location of the study area in Virginia, USA 
Table 1. Morphological characteristics for the 6 tidal marsh creeks. Marsh areas were estimated using a planimeter (and recent aerial photographs). Distances and widths were estimated from topographic maps (1:24000) of the eastern shore

\begin{tabular}{|lcccc|}
\hline Creek & $\begin{array}{c}\text { Marsh area } \\
\text { (ha) }\end{array}$ & $\begin{array}{c}\text { Distance between stations } \\
(\mathrm{km})\end{array}$ & $\begin{array}{c}\text { Width (upper creek) } \\
(\mathrm{m})\end{array}$ & $\begin{array}{c}\text { Width (lower creek) } \\
(\mathrm{m})\end{array}$ \\
\hline Seaside creeks & & & & \\
Greens & 160 & 1.0 & 8 & 20 \\
Phillips & 135 & 1.2 & 8 & 30 \\
Box Tree & 137 & & & 50 \\
Bayside creeks & 1.5 & 1.6 & 250 & 1300 \\
Nassawadox & 18 & 1.2 & 20 & 450 \\
Hungars & 35 & 1.7 & & 500 \\
Cherrystone & 72 & & \\
\hline
\end{tabular}

( $\mathrm{chl}$ a), total suspended solids, organic matter (OM, as volatile suspended solids), particulate and dissolved organic carbon, and inorganic nutrients $\left(\mathrm{PO}_{4}{ }^{3-}, \mathrm{NH}_{4}{ }^{+}\right.$, $\mathrm{NO}_{3}{ }^{-}, \mathrm{NO}_{2}{ }^{-}$) were also measured.

Bacterial abundance and biomass. For determination of bacterial abundance, $1.0 \mathrm{ml}$ of water was collected and immediately preserved in $9.0 \mathrm{ml}$ of filtered $(0.2 \mu \mathrm{m}) 2 \%$ formaldehyde. Bacterial abundance was determined using acridine orange direct counts (Hobbie et al. 1977).

Obvious differences in bacterial cell sizes were noted for the June sampling. Cells from the bayside tidal creeks appeared to be substantially larger than those from the seaside creeks. Therefore, in addition to the other parameters measured, the bacterial biovolume was estimated for the samples collected in July. Photomicrographs were used to calculate bacterial biovolume, using the formula (Krambeck et al. 1981):

$$
V=(\pi / 4) w^{2}(1-w / 3),
$$

where $V$ = biovolume; $w=$ width of the bacterial cell; and $l=$ length of the cell. At least 100 cells were measured for each of the 12 stations.

Cells were separated into 20 size classes, ranging from 0.01 to $1 \mu^{3}$ in $0.02 \mu \mathrm{m}^{3}$ increments. This increment was selected based on the volume of the smallest bacterium measured in the tidal creeks $\left(0.02 \mu^{3}\right)$. Preliminary analysis of the distribution of cell volumes indicated no visible differences among creeks on the same side of the peninsula. This observation was verified by examining the distributions with the Kolmogorov-Smirnoff test. Therefore, all subsequent analyses were carried out on results that were pooled for each side by combining all cell measurements from the bayside creeks into one group and the data from the seaside into another group. The bacterial biomass was calculated using a conversion factor of $0.354 \mathrm{pg} \mathrm{C}$ $\mu \mathrm{m}^{-3}$ (Bjørnsen 1986).

Bacterial productivity. Bacterial productivity was estimated from the rate of incorporation of tritiated thymidine $\left({ }^{3} \mathrm{H}-\mathrm{TdR}\right)$ into DNA (Pollard \& Moriarty 1984). For each sampling location, $20 \mu \mathrm{Ci}{ }^{3} \mathrm{H}-\mathrm{TdR}$ $\left(80 \mathrm{Ci} \mathrm{mmol}^{-1}\right)$ was added to water samples $(10.0 \mathrm{ml})$ and unlabeled thymidine was added. Three concentrations of unlabeled thymidine $(30,60$, and $90 \mathrm{nM})$ were used to allow correction of ${ }^{3} \mathrm{H}-\mathrm{TdR}$ incorporation for isotope dilution (Moriarty \& Pollard 1982, Findlay \& Meyer 1984, Findlay et al. 1984, Chrzanowski 1988 , Findlay et al. 1991). Three live and 3 killed samples were used with $60 \mathrm{nM}$; 2 live and 2 killed samples were used at both 30 and $90 \mathrm{nM}$. The reactions were stopped after $30 \mathrm{~min}$ with $1 \mathrm{ml}$ of buffered formaldehyde $(2 \%)$, and the samples were immediately placed on ice. The amount of isotope dilution was highly variable ( 0 to $75 \%)$ and differed among sampling locations and times.

Extraction of the cold-TCA-insoluble fraction was performed within $6 \mathrm{~h}$ of sample collection. The bacteria were filtered through $0.45 \mu \mathrm{m}$ pore diam. polycarbonate filters, rinsed with $15 \mathrm{ml}$ of ice-cold $80 \%$ ethanol, then rinsed 3 times with $10 \mathrm{ml}$ ice-cold $3 \%$ trichloroacetic acid (TCA). The filters were placed in $10.0 \mathrm{ml}$ of $5 \%$ TCA for $72 \mathrm{~h}$ at room temperature to hydrolyze the DNA. A $1 \mathrm{ml}$ portion of the sample was placed in a $20 \mathrm{ml}$ scintillation vial which was then filled with scintillation cocktail. Radioactivity was measured using a Beckman LS-7500 liquid scintillation counter and corrected for quench using $\mathrm{H}^{\#}$.

Bacterial productivity was calculated as cells $\mathrm{ml}^{-1}$ $\mathrm{h}^{-1}$ as described in Moriarty \& Pollard (1981) using their conversion factor of $1.3 \times 10^{18}$ cells $\mathrm{mol}^{-1} \mathrm{TdR}$. This conversion factor, when combined with isotope dilution corrections, is within the range of conversion factors for marine, estuarine, and freshwater systems that are reported in the literature. Carbon-based productivity was not calculated for the June samples because our measurements of biovolume invalidated the assumptions of uniform cell size inherent in such a calculation. For the July samples, bacterial productivity was calculated as $\mathrm{ng} \mathrm{C} \mathrm{ml} \mathrm{m}^{-1} \mathrm{~h}^{-1}$ for each sample by 
multiplying bacterial productivity (cells $\mathrm{ml}^{-1} \mathrm{~h}^{-1}$ ) by the average measured biovolume of the cells and a cell

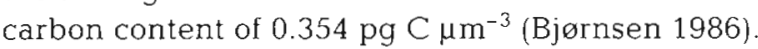

Physical-chemical parameters. For chl a determinations, $500 \mathrm{ml}$ water samples were collected and stored in brown plastic containers. The samples were filtered through glass-fiber filters (Gelman, GFC) within $4 \mathrm{~h}$ of collection, and the filters were refrigerated for up to $1 \mathrm{wk}$ prior to pigment extraction. Pigments were extracted by grinding the filters in a $3: 2$ $90 \%$-acetone:DMSO solution (Shoaf \& Lium 1976. Jonas \& Tuttle 1990). The resulting mixture was incubated at $4{ }^{\circ} \mathrm{C}$ for $24 \mathrm{~h}$ and then centrifuged for $20 \mathrm{~min}$ at $5000 \times g$. Absorption was measured at 750 and $664 \mathrm{~nm}$ before and after acidification with $0.1 \mathrm{~N} \mathrm{HCl}$ to correct for pheopigment absorption.

Water samples $(500 \mathrm{ml})$ were collected for TSS and stored on ice for return to the laboratory where 200 to $400 \mathrm{ml}$ of water were passed through preweighed glass-fiber filters (Gelman, GFC) within $4 \mathrm{~h}$ of sampling. The TSS weight was determined after drying the samples for $24 \mathrm{~h}$ at $110^{\circ} \mathrm{C}$. To determine ash-free dry weight (AFDW $=$ OM), the TSS samples were placed in a muffle furnace for $24 \mathrm{~h}$ at $450^{\circ} \mathrm{C}$. Samples for DOC were filtered $(0.2 \mu \mathrm{m}$ Gelman) at the time of sample collection and preserved by adjusting the $\mathrm{pH}$ to 2 with concentrated $\mathrm{H}_{2} \mathrm{SO}_{4}$ and immediately placing the samples on ice. DOC concentrations were measured using UV-assisted persulfite digestion in a Dohrmann TOC analyzer.

Nutrients. Water used for nutrient determinations $(100 \mathrm{ml})$ was filtered though membrane filters (Gelman GN-6, $0.45 \mu \mathrm{m}$ pore diam.). Methods described by Grassoff et al. (1983) were used for nutrient analyses. Phosphate concentration was determined using a combined ammonium molybdate, sulfuric acid, ascorbic acid, potassium antimony tartrate reagent. To determine the $\mathrm{NH}_{4}{ }^{+}$concentration, tri-sodium citrate, phenol, and hypochlorite reagents were used. The concentration of $\mathrm{NO}_{2}{ }^{-}$was determined using sulfanilamide and $\mathrm{N}$-[1-naphthyl]-ethylene diamine dihydrochloride reagents. To determine the concentration of $\mathrm{NO}_{3}{ }^{-}$, the $\mathrm{NO}_{3}{ }^{-}$in the samples was reduced to $\mathrm{NO}_{2}{ }^{-}$ by passing $50 \mathrm{ml}$ of water though a cadmium-reduction column. These samples were then analyzed for $\mathrm{NO}_{2}^{-}$.

Statistical analysis. Multivariate analysis of variance (MANOVA) was performed to evaluate differences between sides of the peninsula, locations within creeks (i.e. upper vs lower), sampling times, and individual creeks. A Kolmogorov-Smirnoff test was used to assess the similarities of the frequency distributions of the cell biovolumes between bayside and seaside water samples. SPSS PC+ (version 4.0) was used to perform both of these tests. The $\alpha$-level used to determine significance was set at 0.05 for all tests

\section{RESULTS}

\section{Abundance and biovolume}

Bacterial abundance was almost always higher at all bayside stations than at any seaside station (Table 2). The MANOVA results (Table 3 ) indicated the differences were significant (the grand means for July were $12 \times 10^{6}$ and $3.8 \times 10^{6}$ cells $\mathrm{ml}^{-1}$ for the bayside and seaside creeks respectively; see Fig. 3). There were also significant differences in abundance between the June and July sampling times (Table 2). For example, in upper Cherrystone Creek the bacterial abundance was $4.27 \times 10^{6}$ and $1.87 \times 10^{7}$ cells $\mathrm{ml}^{-1}$ in June and July, respectively. In general, the upper creek locations contained more bacteria than the lower creek locations, with the exception of Nassawadox Creek where there was little difference between the upper and lower sites. The overall effect of the upper vs lower location comparison (Table 3) was significant.

Differences in the size of the bacteria between the bayside and seaside creeks were noticed in the June samples. These differences were confirmed when cell size was measured in July. The relative frequency distribution for bacterial biovolume was significantly different for the bayside as compared to the seaside (Fig. 2). Although the smallest size category $(0$ to 0.02 $\mu \mathrm{m}^{3}$ ) contained the most cells regardless of sampling location, a greater proportion of the total number of cells from the seaside fell into the smallest size class ( $40 \%$ seaside, $23 \%$ bayside). There were very few large cells in the seaside samples, while there were many more cells with large biovolumes in the bayside water.

The total biovolume in each size class was calculated (Fig. 2). For the bayside samples, the bacterial cells within the $0.22 \mu^{3}$ size class contained the most carbon (40 $\mathrm{ng} \mathrm{C} \mathrm{ml} \mathrm{m}^{-1}$ ). Alternatively, the cells in the $0.04 \mu \mathrm{m}^{3}$ size class contained the most carbon for seaside samples $\left(18 \mathrm{ng} \mathrm{C} \mathrm{ml}^{-1}\right.$ ). Similar to the relative frequency distribution, little carbon was contained in the larger cells of the seaside creeks $\left(<10 \mathrm{ng} \mathrm{C} \mathrm{ml}^{-1}\right.$ for all cells with a biovolume greater than $0.3 \mu \mathrm{m}^{3}$ ). However, the large cells from the bayside contained a significant proportion of the total carbon (>100 ng $\mathrm{C} \mathrm{ml}^{-1}$ for all cells larger than $0.3 \mu \mathrm{m}^{3}$ ).

\section{Bacterial productivity}

Higher rates of bacterial productivity were measured on the bayside than the seaside. Productivity was also higher in the upper than the lower creeks, and greater in June than in July (Table 2), and all differences were statistically significant (Table 3 ). In July, the average 
Table 2. Values for biological and chemical factors measured in tidal creeks of the eastern shore of Virginia in June and July 1991. All values are the mean of 3 (independent) replicates. Biovolumes (and therefore carbon-based productivity) were only measured in July. DOC: dissolved organic carbon; TSS: total suspended solids; OM: organic matter. Error values are not given for the sake of clarity, but the results of the MANOVA analysis are given in Table 3

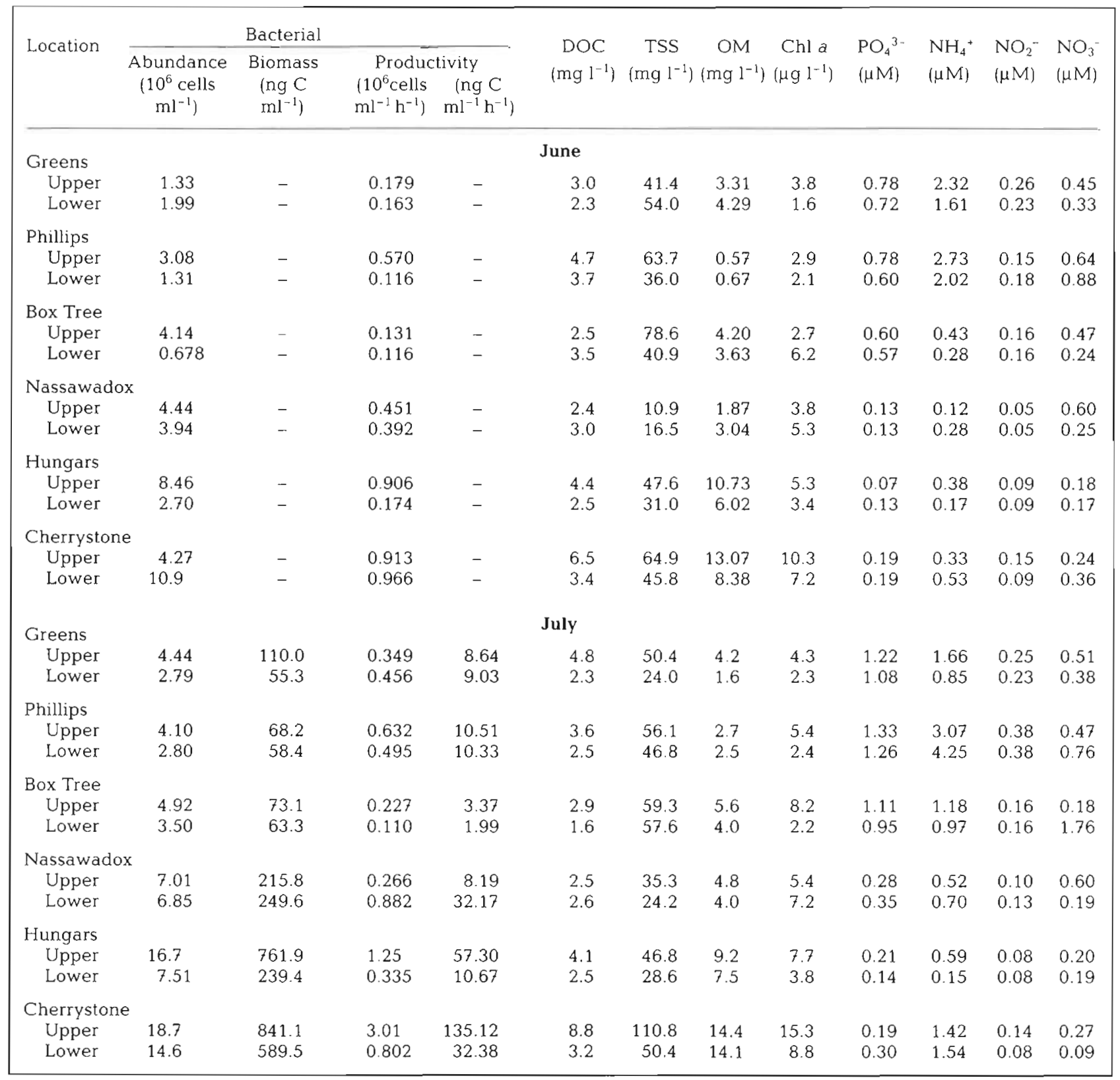

Table 3. Significance of the F-statistic for MANOVA results. Independent variables (treatments) include: Side (bayside vs seaside); Location (upper or lower position in the tidal creek); Time (June vs July); and Creek (individual tidal creek). The a priori $\alpha$-level for determining significance was set at 0.05 . Abbreviations as in Table 2

\begin{tabular}{|lcccccccccccc}
\hline Variable & Abundance & Productivity & DOC & TSS & $\begin{array}{c}\text { OM } \\
\text { Amount } \%\end{array}$ & Chla & $\mathrm{PO}_{4}{ }^{3-}$ & $\mathrm{NH}_{4}{ }^{+}$ & $\mathrm{NO}_{3}{ }^{-}$ & $\mathrm{NO}_{2}{ }^{-}$ \\
\hline Side & & & & & & & & & \\
Location & 0.00 & 0.00 & 0.44 & 0.12 & 0.00 & 0.13 & 0.00 & 0.00 & 0.00 & 0.02 & 0.00 \\
Time & 0.00 & 0.00 & 0.00 & 0.00 & 0.00 & 0.50 & 0.00 & 0.02 & 0.59 & 0.40 & 0.09 \\
Creek & 0.00 & 0.00 & 0.89 & 0.03 & 0.00 & 0.38 & 0.02 & 0.00 & 0.03 & 0.41 & 0.00 \\
& & 0.00 & 0.00 & 0.00 & 0.00 & 0.22 & 0.00 & 0.00 & 0.00 & 0.23 & 0.00 \\
\hline
\end{tabular}



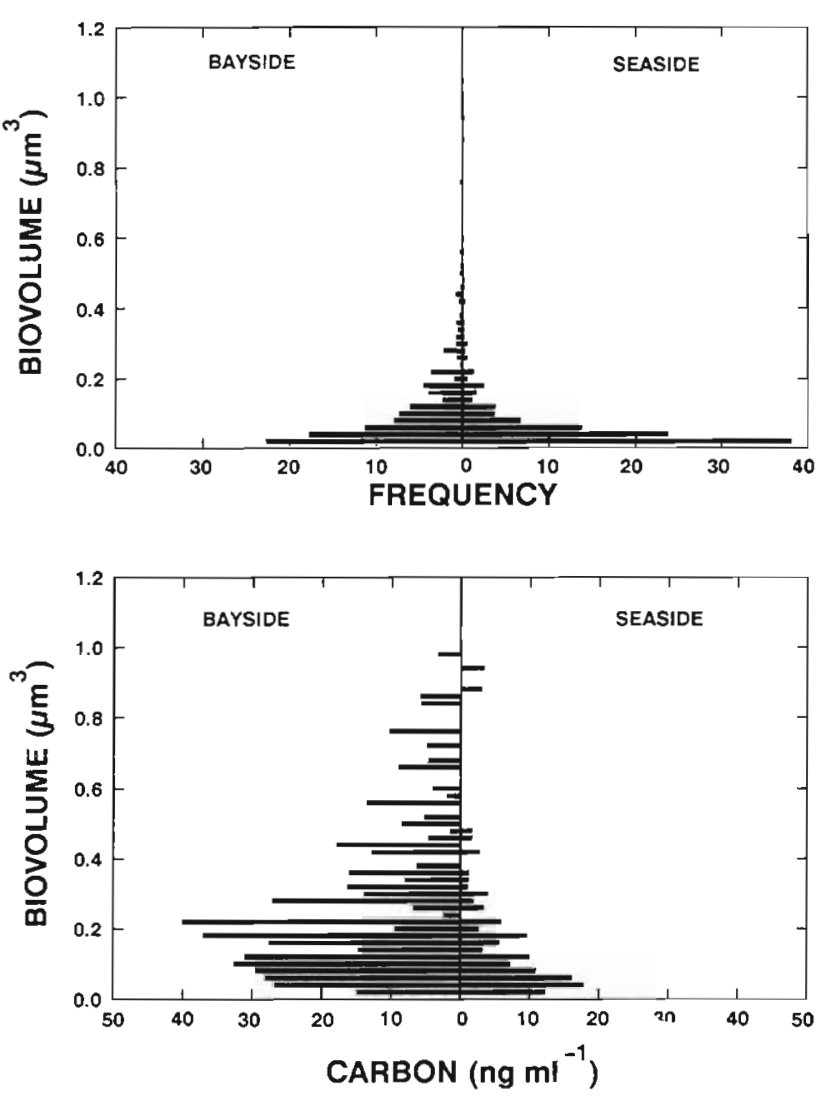

Fig. 2. Bacterial size class distribution expressed as frequency of occurrence (above) and as ng $\mathrm{C} \mathrm{ml}^{-1}$ (below). Size classes are $0.02 \mu \mathrm{m}^{3}$ Samples were collected during July 1991. Data

are pooled for all creeks on each side of the peninsula

bacterial productivity in the bayside creeks was $1.09 \times$ $10^{6}$ cells $\mathrm{ml}^{-1} \mathrm{~h}^{1}\left(46 \mathrm{ng} \mathrm{C} \mathrm{ml}^{-1} \mathrm{~h}^{-1}\right)$ compared to $0.38 \times$ $10^{6}$ cells $\mathrm{ml}^{-1} \mathrm{~h}^{-1}\left(7.3 \mathrm{ng} \mathrm{C} \mathrm{ml} \mathrm{m}^{-1} \mathrm{~h}^{-1}\right)$ in the seaside creeks (Fig. 3). In Hungars Creek during July, the bacterial productivity was $1.25 \times 10^{6}$ cells $\mathrm{ml}^{-1} \mathrm{~h}^{-1}$ (57 $\mathrm{ng} \mathrm{C} \mathrm{ml}^{-1} \mathrm{~h}^{-1}$ ) at the upper location and $0.34 \times 10^{6}$

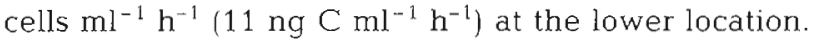
The bacterial productivity in upper Cherrystone Creek was $9.1 \times 10^{5}$ cells $\mathrm{ml}^{-1} \mathrm{~h}^{-1}$ during June and $3.0 \times 10^{5}$ cells $\mathrm{ml}^{-1} \mathrm{~h}^{-1}$ during July. June samples could not be expressed in terms of carbon because biovolume measurements had not been made.

When bacterial turnover times were calculated, there were no significant differences between sides, locations, or times (data not shown; mean bacterial cell or bacterial carbon turnover time for all stations and times $=25 \mathrm{~h}$ )

\section{Physical-chemical parameters}

The creeks of the bayside and seaside contained similar concentrations of TSS (Table 2). In July, the average TSS concentration for all bayside and seaside creeks was the same (approximately $49 \mathrm{mg} \mathrm{l}^{-1}$; Fig. 3). Significant differences in the organic component of the TSS (ash-free dry weight) were observed between creeks on the seaside vs bayside (Table 3) and both Hungars and Cherrystone creeks contained much higher concentrations of organic matter than the other creeks (Table 2). For example, upper Cherrystone Creek contained $14.4 \mathrm{mg} \mathrm{l}^{-1}$ organic matter in July compared to upper Greens Creek which contained only $4.2 \mathrm{mg} \mathrm{l}^{-1}$ organic matter.

The amount of organic matter was significantly different for the bayside vs seaside creeks, and, similar to the distribution of concentrations of organic matter in the suspended particles, the concentrations of organic matter were higher in the bayside tidal creeks. Values were particularly high in upper Hungars Creek (10.7 $\mathrm{mg}^{-1}$ in June) and upper Cherrystone Creek (13.1 mg $\mathrm{1}^{-1}$ in June, compared with $0.6 \mathrm{mg} \mathrm{l^{-1 }}$ in upper Phillips Creek). It is likely that algal biomass contributed significantly to the organic matter content of the water because the concentration of chl a was greater in the bayside creeks than the seaside creeks. In July, there was an average of $6.0 \mu \mathrm{g} \mathrm{l}^{-1} \mathrm{chl} a$ in the bayside creeks and only $4.1 \mu \mathrm{g} \mathrm{J}^{-1}$ in the seaside creeks (Fig. 3)

The amount of DOC was similar in the tidal creeks on the bayside and seaside at all sampling times. For example, in July the average DOC concentration was $3.9 \mathrm{mg} \mathrm{l}^{-1}$ in the bayside creeks and $3.0 \mathrm{mg} \mathrm{I}^{-1}$ in the seaside creeks (Fig. 3). The concentrations of DOC did not vary from June to July (Table 2); however, there were distinct differences between the sampling locations within the creeks. In July, upper Cherrystone Creek contained $8.8 \mathrm{mg} \mathrm{l}^{-1}$ DOC while lower Cherrystone Creek contained only $3.2 \mathrm{mg} \mathrm{l}^{-1}$ DOC. The turnover time for DOC was calculated by dividing the DOC concentration by bacterial productivity. The turnover time for the standing stock of DOC was much more rapid on the bayside (5.9 d) than the seaside ( $21.2 \mathrm{~d}$ ). This difference existed despite the fact that the calculated bacterial cell turnover times were similar for the seaside and bayside (because of the significantly larger bacterial biomass in the bayside creeks).

\section{Nutrients}

In general, the nutrient concentrations on the bayside were substantially lower than those on the seaside. Mean $\mathrm{NH}_{4}{ }^{+}$concentration for all bayside creeks at both sampling times was $0.6 \mu \mathrm{M}$, and was significantly dif-

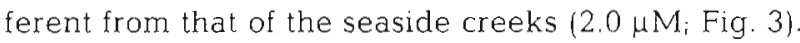
There was also a significant time difference with the July concentrations of nutrients being greater (Tables 2 \& 3). Differences between creeks on the same side of the Delmarva Peninsula were also apparent, except for 
$\mathrm{NO}_{3}{ }^{-}$which was highly variable for each individual sample (Table 2). Samples collected at the upper and lower locations within each creek were not different with the exception of $\mathrm{PO}_{4}{ }^{3-}$. Phosphate concentrations were consistently higher at the upper creek locations

Ammonia was the dominant form of nitrogen for all samples evaluated at all times. In the cases of Phillips and Greens Creeks, $\mathrm{NH}_{4}{ }^{+}$concentrations were as much as 3 times greater than those of $\mathrm{NO}_{3}{ }^{-}$and $\mathrm{NO}_{2}{ }^{-}$combined (Phillips: $2.3 \mu \mathrm{M}$ $\mathrm{NH}_{4}^{+}, 0.71 \mu \mathrm{M} \quad \mathrm{NO}_{3}^{-}+\mathrm{NO}_{2}^{-} ;$Greens: $2.7 \mu \mathrm{M} \mathrm{NH}{ }_{4}^{+}, 0.79 \mu \mathrm{M} \mathrm{NO}_{3}^{-}+\mathrm{NO}_{2}{ }^{-}$).

All of the creeks examined in this study are well mixed from top to bottom so that concentrations of dissolved species and water temperatures are consistent throughout the entire water column. Water temperatures ranged from 24 to $29^{\circ} \mathrm{C}$ in June and from 27 to $31^{\circ} \mathrm{C}$ in July. No differences in water temperature in any of the statistical comparisons made were significant. Creek water oxygen concentrations ranged from 6 to $11 \mathrm{mg} \mathrm{l^{-1 }}$ during June and July. No significant oxygen concentration differences were observed among the creeks. Salinities ranged from 26 to $33 \mathrm{ppt}$ on the seaside and 17 to 23 ppt on the bayside. Salinity effects could not be separated from the side (bay- vs seaside) effects. Additionally, there were no relationships between salinity and DOC turnover or bacterial abundance, productivity, and biovolume within either side. However, the limited data set available at this time precludes making definitive statements about salinity effects in these systems.

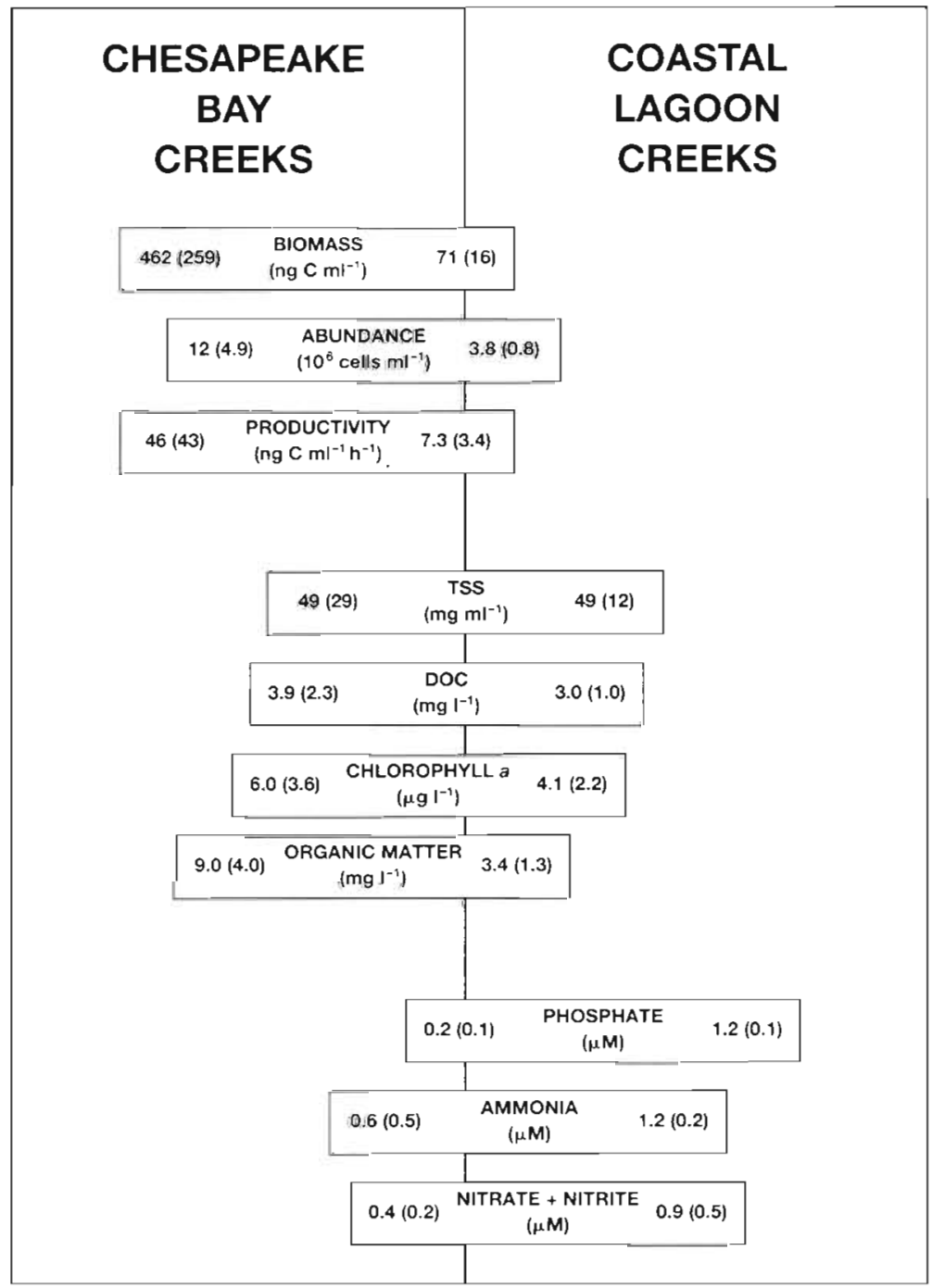

Fig. 3. Average values (with 1 SD) of measured parameters for bayside locations and seaside locations in July. The portion of the bar on each side of the line represents relative magnitude of the value for each parameter. Top 3 bars characterize the bacteria, middle 4 bars are other important biological variables, and bottom 3 bars represent inorganic nutrient concentrations

\section{DISCUSSION}

Obvious differences in the bacterial parameters measured were observed between the bayside and seaside marsh creeks. Microbial abundance and biovolume (i.e. biomass) were significantly greater on the bayside as compared to the seaside. Bacterial turnover times were similar; thus, DOC turnover was significantly greater for the bayside samples due to the greater bacterial biomass found there. These differences may be reflected in the bacterial processing of carbon in these tidal marsh creeks

Many of the factors measured were elevated at the upper sampling locations in each creek relative to the lower sites even though the samples were taken at high tide, when differences should be minimal (Stevenson et al. 1974, Erkenbrecher \& Stevenson 1975, Chambers 1990). At high tide most of the water in the creeks has been brought in by the tide so that at high tide most of the water in the seaside creeks has come from the coastal lagoon complex and the water in the bayside creeks has come from the Chesapeake Bay. Thus the input of materials from the marsh surface would be diluted by the flooding water. At low tide it might be expected that the concentrations of TSS, DOC, and nutrients would be greater than at high tide and the differences between upper and lower locations might be more pronounced. In fact, when samples 
were collected though a tidal cycle in Phillips Creek, the greatest concentrations of nutrients occurred at low tide (Chambers 1990). Elevated levels of bacteria, organic, and inorganic compounds in waters at the upper locations suggests a strong influence of the more extensive marshes there on the composition of the tidal creek water even at high tide. Based on the earlier work (Stevenson et al. 1974, Erkenbrecher \& Stevenson 1975, Chambers 1990), we might expect the differences to be even greater during falling tides.

The differences in chl a concentrations between upper and lower sampling locations correlated with differences in the other measured biological parameters. Chl a concentrations were higher at upper sites and may have been related to the higher nutrient concentrations measured there. In addition, the greater bacterial abundance at upper sites could be due to higher concentrations of DOC and organic matter in the creek water at the upper locations. Erkenbrecher \& Stevenson (1975) measured the influence of tidal flux on microbial biomass in salt marsh creeks and found that microbial abundance was correlated with POC concentrations at locations which were similar to our upper and lower sites (although their upper and lower sites were not located in the same creek). The greater microbial abundance and organic matter concentration observed at upper creek locations in our study were not seen by Erkenbrecher \& Stevenson (1975). This discrepancy may be related to the differences between their tidal creeks that masked the influence of the sampling location. Their 'lower' creek site had a soft, silty-clay bottom, while their 'upper' creek site had a firm, sandy bottom. It is likely that differences in microbial abundance and POC that they observed were related to differences in creek sediments: greater abundance and POC resulted from resuspension of fine sediments.

Many of the measured parameters were greater during July as compared to June. The small differences in water temperature observed in June and July are not likely to be responsible for these differences. The water temperature ranged from 25 to $29^{\circ} \mathrm{C}$ during June and from 28 to $31{ }^{\circ} \mathrm{C}$ during July. A better explanation of these differences is the length of time that the waters were at the warmer temperature. Temperatures in the creeks increased rapidly though May and June and remained near $30^{\circ} \mathrm{C}$ throughout the rest of the summer. Therefore, when samples were collected in June, the temperature had just reached summer values and biological activity would have been in the process of responding to the increased temperatures, while in July, the temperature had been elevated for more than a month and biological activity would have reached the summer maximum. Monthly sampling of the seaside creeks for a 2 yr period indicated that biological activity reached a peak in July and remained high until October (Mills et al. 1990).

In July, the concentration of chl $a$ and bacterial productivity and abundance were higher than obtained in June. Correlations between primary production and bacterial abundance and productivity are common across a range of aquatic ecosystems. Cole et al. (1988) suggested 2 mechanisms that could explain these relationships: either the same factors that limit phytoplankton productivity also limit bacterial productivity, or bacterial productivity is controlled by phytoplankton productivity. These mechanisms can be applied to the bayside and seaside creeks in our study. For example, the high nutrient concentrations, low chl $a$, and bacterial productivity in the seaside creeks may indicate that both algal and bacterial growth are limited by a common factor. Alternatively, the correlation between chl $a$ and bacterial productivity may indicate a direct link between the phyto- and bacterioplankton (Ducklow et al. 1986).

Striking differences were observed between creeks of the bayside and seaside shores of the peninsula (Fig. 3). There were significantly more and bigger bacteria (mean cell biovolume was 0.12 and $0.05 \mu \mathrm{m}^{3}$, bayside and seaside respectively) in the water of the bayside creeks. The bacterial size-class distribution was also significantly different. Most of the bacteria in both the bayside and seaside creeks were very small $\left(<0.02 \mu^{3}\right)$, but a significant amount of carbon was contained in the largest cells of the bayside creeks. Cells of an equivalent size were virtually non-existent in the coastal lagoon creeks.

There are several explanations for the difference in the cell-size distribution. Size differences may be related to differences in community composition, sizeselective grazing, or substrate quality including, but not limited to, differences in efficiency of assimilation of the carbon present. It is possible that the bacteria from the bayside tidal creeks were in fact larger than the bacteria from the seaside creeks. Alternatively, the different creeks may contain different types of bacteria which are characterized by larger cell biovolumes. However, the results from an examination of the community structure using the approach of Garland \& Mills (1991) showed that the bacteria from the bayside and seaside were capable of utilizing the same sources of carbon (data not shown). The Garland \& Mills approach involves classification of intact microbial communities based on patterns of sole-carbon-source utilization when a water sample is inoculated into a variety of media each containing a single carbon source. The results from this type of community structure analysis suggest that the bacteria on the bayside and seaside are performing the same functions and may, in fact, be the same type of bacteria. 
It is also possible that bacterivory influences the frequency distribution of bacterial biovolumes. Bacterivory can also influence both bacterial abundance and biomass. Many investigators believe that a balance exists between bacterial growth and bacterivory which keeps the number of bacteria relatively constant (Azam et al. 1983, Güde 1989). It has also been suggested that in some ecosystems, protozoans preferentially graze upon large cells and therefore influence the distribution of bacteria in terms of size (Gonzalez et al. 1990). Perhaps the grazers present in the bayside and seaside tidal marsh creeks are different, although we have no data to suggest that such is the case.

Morita (1982) observed that the availability of energy-yielding substrate influenced the size of bacteria. Extremely small or 'ultramicrobacteria' $(<0.3 \mu \mathrm{m}$ diam.) were produced in response to low substrate levels. Morita suggests that a decrease in cell size is advantageous under conditions of low substrate concentrations because the increase in cell surface to volume ratio increases the efficiency with which the bacteria can obtain substrate. If the bacteria are smaller in the seaside creeks, they could be limited by the availability of nutrients or an energy source. Because the nutrient concentrations in the seaside creeks are relatively high, it is unlikely that the bacteria in these creeks were limited by the availability of nitrogen or phosphorus. In addition, the concentrations of DOC were very similar in the bayside tidal creeks compared to seaside tidal creeks (Fig. 3). However, DOC turnover times were much faster on the bayside than on the seaside (5.9 and $21.2 \mathrm{~d}$, respectively) and could suggest that the quality of the DOC may be very different. If there is less labile $\mathrm{DOC}$ in the seaside creeks, then perhaps the bacterial cell size distribution reflects the relative efficiency of substrate utilization.

Our conclusion that bacterial productivity and DOC turnover were much greater in the bayside than the seaside creeks depends on several assumptions. The first is that cell yield per mole of thymidine incorporated is constant for all sampling locations and at each sampling time. The factor that we have used, $1.3 \times 10^{18}$ cells $\mathrm{mol}^{-1} \mathrm{TdR}$, is derived from the assumption that thymidine constitutes an average of $25 \%$ of the bases in bacterial DNA (range 12 to $36 \%$ ) and that the genome size is $2.5 \times 10^{9}$ daltons (range $1 \times 10^{9}$ to $3.6 \times$ $10^{9}$ ) (Moriarty \& Pollard 1981). Cole et al. (1988) reviewed variation in the thymidine conversion factor for a wide range of aquatic systems and Scavia et al. (1986) have shown that the thymidine conversion factor may vary within, as well as between, systems. Bell (1986) suggested that the wide variation that has been observed in the thymidine conversion factor might be accounted for in part by isotope dilution. Our calculations of bacterial productivity have been corrected for isotope dilution which was measured for every sample so that differences in the thymidine conversion factor would be minimal. Another assumption that might alter our estimates of bacterial productivity and thus DOC turnover is that the carbon conversion factor (biovolume to bacterial carbon) is constant. The value that we have used $\left(0.354 \mathrm{pg} \mu \mathrm{m}^{-3}\right)$ is based on measurements made by Bjornsen (1986), who found that this value was constant for the freshwater and estuarine systems that he examined. Finally, we have also assumed that bacterial growth efficiencies were similar between the bayside and seaside marsh creeks. For bacterial productivity and DOC turnover of the bayside creeks to be the same as those of the seaside creeks, the thymidine conversion factor, carbon conversion factor, or the growth efficiency (or some combination thereof) for the bayside creeks would have to be 2 -fold smaller than the values used. We are presently conducting experiments to address the validity of these assumptions

A convincing case has been made for the connection between nutrient loading and eutrophication in Chesapeake Bay (Boynton et al. 1982, Correll 1987, Fisher \& Doyle 1988, Malone 1988). The high inorganic nutrient concentrations present in the seaside tidal creeks suggest that the conclusions drawn for the Chesapeake may not apply to the coastal lagoon complex, at least on the lower Delmarva Peninsula. The high concentrations of nutrients, especially in Phillips and Greens Creeks, may be associated with the agricultural fields which surround these marshes. Despite these higher concentrations of nutrients (presumably from high loadings), the standing stock of chl $a$ is significantly less in the seaside tidal creeks and the bacteria are less abundant, have less biomass, and are less productive. Although chl a standing stocks are not a measure of phytoplankton productivity, Boynton et al. (1982) compared the relationship between these 2 measures for 39 estuarine systems and found that the chl a concentrations paralleled those of phytoplankton production. A lower overall standing crop of phytoplankton and a less-active bacterial community associated with high inorganic nutrient concentrations in the seaside creeks might suggest that a factor other than inorganic nutrients limits productivity. High concentrations of available $\mathrm{N}$ and $\mathrm{P}$ in water do not always mean that those nutrients are not limiting phytoplankton production (Correll 1987). Alternative controls on phytoplankton could include light limitations, flushing rates (Boynton et al. 1982), or grazing (Wright \& Coffin $1984 a, b)$

Although we have not directly examined limitations on phytoplankton productivity, the observations reported here suggest that water-quality-management plans based on a direct link between nutrient loading 
and phytoplankton productivity may not produce any observable change in aquatic productivity in this CLC or other systems with similar behavior. A detailed examination of this question could provide the necessary information on which to base management decisions.

Regardless of the controls on phytoplankton productivity, our data suggest that the impact of nitrogen inputs in these 2 systems differ. We believe that this difference is related to the difference in the quality of available carbon and energy substrates. On the seaside, inorganic nitrogen concentrations are higher and bacterial productivity is lower than on the bayside. The seaside tidal creeks are surrounded by extensive salt marshes and chl a concentrations are relatively low. This suggests that the seaside DOC and organic matter are derived from primarily marsh grasses which is usually thought to be of lower quality than organic material derived from phytoplankton (Moran \& Hodson 1990). Understanding the links between the quantity and quality of carbon and energy substrates and nitrogen cycling in aquatic ecosystems is essential to understanding the impact that inorganic nutrients will have on primary production, oxygen depletion, and trophic structure in these systems.

Acknowledgements. This research was supported by a National Science Foundation grant BRS87-02333-04 to the Virginia Coast Reserve Long Term Ecological Research Program and a Fred H. Moore Research Fellowship from the Department of Environmental Sciences at the University of Virginia.

\section{LITERATURE CITED}

Azam, F., Fenchel, T., Field, J. S., Gray, J. G., Meyer-Reil, L. A., Thingstad, F. (1983). The ecological role of watercolumn microbes in the sea. Mar. Ecol. Prog. Ser. 10: $257-263$

Bell, R. T. (1986). Further verification of the isotope dilution approach for estimating the degree of participation of $\left[{ }^{3} \mathrm{H}\right]$ thymidine in DNA synthesis in studies of aquatic bacterial production. Appl. environ. Microbiol. 52: 1212-1214

Bjørnsen, P. K. (1986). Automatic determination of bacterioplankton biomass by image analysis. Appl. environ. Microbiol. 51: 1199-1204

Boynton., W. R., Kemp, W. M., Keefe, C. W. (1982). A comparative analysis of nutrients and other factors influencing estuarine phytoplankton production. In: Kennedy, V. S. (ed.) Estuarine comparisons. Academic Press, New York, p. $69-90$

Chambers, R. M. (1990). Nitrogen and phosphorus dynamics in tidal freshwater marshes. Ph.D. dissertation, Univ. of Virginia, Charlottesville

Chrzanowski, T H. (1988). Consequences of accounting for isotopic dilution in thymidine incorporation assays. Appl. environ. Microbiol. 54: 1868-1870

Cole, J. J., Findlay, S., Pace, M. L. (1988). Bacterial production in fresh and saltwater ecosystems: a cross-system overview. Mar. Ecol. Prog. Ser. 43:1-10
Correll, D. L. (1987). Nutrients in Chesapeake Bay. In: Majumdar, S. K., Hall, L. W. Jr, Austin, H. M. (eds.) Contaminant problems and management of living Chesapeake Bay resources. Pennsylvania Academy of Science, Phillipsburg, p. 298-320

Day, J. W. Jr. Hall, C. S., Kemp, W. M., Yanez-Arancibia, A. (1989). Estuarine ecology. John Wiley and Sons, New York

Ducklow, H. W., Purdie, D. A. Williams, P. J. L., Davies, J. M. (1986). Bacterioplankton: a sink for carbon in a coastal marine plankton community. Science 232: 865-867

Erkenbrecher, C. W., Stevenson, L. H. (1975). The influence of tidal flux on microbial biomass in salt marsh creeks. Limnol. Oceanogr. 20: 618-625

Findlay, S., Meyer, J. L. (1984). Significance of bacterial biomass and production as an organic carbon source in lotic detrital systems. Bull. mar. Sci. 35: 318-325

Findlay, S., Meyer, J. L., Edwards, R. T (1984). Measuring bacterial production via rate of incorporation of $\left[{ }^{3} \mathrm{H} \mid\right.$ thymidine into DNA. J. microbiol. Meth. 2: 57-72

Findlay, S., Pace, M. L., Lints, D., Cole, J. J., Caraco, N. F., Peierls, B. (1991). Weak coupling of bacterial and algal production in a heterotrophic ecosystem: the Hudson River estuary. Limnol. Oceanogr 36: 268-278

Fisher, T. R. Doyle, R. D. (1988). Nutrient cycling in Chesapeake Bay. In: Mackiernan, G. B. (ed.) Dissolved oxygen in the Chesapeake Bay: processes and effects. Maryland Sea Grant Publication UM-SG-TS-78-03. Univ. of Maryland, College Park, p. 49-53

Garland, J. L., Mills, A. L. (1991). Classification and characterization of heterotrophic microbial communities on the basis of patterns of community-level sole-carbon-source utilization. Appl environ. Microbiol. 57: 2351-2359

Gonzalez, J. M., Sherr, E. B., Sherr, B. F. (1990). Size-selective grazing on bacteria by natural assemblages of estuarine flagellates and ciliates. Appl. environ. Microbiol. 56: $583-589$

Grasshoff, K., Ehrhardt, M., Kremeling, K. (1983). Methods of seawater analysis. Verlag Chemie, Weinheim

Güde, H. (1989). The role of grazing on bacteria in plankton succession. In: Sommer, U. (ed.) Plankton ecology: succession in plankton communities. Brock/Springer, New York, p. $337-364$

Hobbie, J. E., Daley, R. J., Jasper, S. (1977). Use of Nuclepore filters for counting bacteria by fluorescence microscopy. Appl. environ. Microbiol. 33: 1225-1228

Jonas, R. B. (1992). Microbial processes, organic matter and oxygen demand in the water column. In: Smith, D. E., Leffler, M., Mackiernan, G. (eds.) Oxygen dynamics in Chesapeake Bay: a synthesis of recent research. Maryland Sea Grant Publication UM-SG-TS-92-01 Univ. of Maryland, College Park, p. 61-11.2

Jonas, R. B., Tuttle, J. H. (1990). Bacterioplankton and organic carbon dynamics in the lower mesohaline Chesapeake Bay, Appl environ. Microbiol. 56: 747-757

Krambeck, C., Krambeck, H.-J, Overbeck, J (1981). Microcomputer-assisted biomass determination of plankton bactena on scanning electron micrographs. A.ppl. environ. Microbiol. 42; 142-149

Malone, $T$ C. (1992). Effects of water column processes on dissolved oxygen, nutrients, phytoplankton and zooplankton. In: Smith, D. E., Leffler, M., Mackiernan, G. (eds.) Oxygen dynamics in Chesapeake Bay: a synthesis of recent research. Maryland Sea Grant Publication UM-SGTS-92-01. Univ. of Maryland, College Park, p. 61-112

Malone, T. C. (1988). Seasonal oxygen depletion and phytoplankton production in Chesapeake Bay: preliminary results of 1985-1986 field studies. In: Mackiernan, G. B. 
(ed.) Dissolved oxygen in the Chesapeake Bay: processes and effects. Maryland Sea Grant Publication UM-SG-TS78-03. Univ. of Maryland, College Park, p. 54-60

Mills, A. L., Blum, L. K., Lagera, L. M. (1990). Distribution of bacterial abundance and activity in the Virginia Coastal Lagoon. Abstract Ann. Meeting Am. Soc. Limnol. Oceanogr., Williamsburg, VA

Moran, M. A., Hodson, R. E. (1990). Contributions of degrading Spartina alterniflora lignocellulose to the dissolved organic carbon pool of a salt marsh. Mar Ecol. Prog. Ser 62: $161-168$

Moriarty, D. J., Pollard, P. C. (1981). DNA synthesis as a measure of bacterial productivity in seagrass sediments. Mar. Ecol. Prog. Ser. 5: 151-156

Moriarty, D. J., Pollard, P. C. (1982). Diel variation of bacterial productivity in seagrass (Zostera capricorni) beds measured by rate of thymidine incorporation into DNA. Mar. Biol. 72: 165-173

Morita, R. Y. (1982). Starvation-survival of heterotrophs in the marine environment. Adv. microb. Ecol. 6: 171-198

Nixon, S. C. (1982). Nutrient dynamics, primary production and fisheries yields of lagoons. In: Lasserre, P., Postma $\mathrm{H}$. (eds.) Proc. Int. Symp. Coastal Lagoons. SCOR/IABO/ UNESCO, Bordeaux. Oceanologica Acta V4 (Suppl.): $357-371$

Pollard, P. C., Moriarty, D. J. (1984). Validity of the tritiated thymidine method for estimating bacterial growth rates: measurement of isotope dilution during DNA synthesis Appl. environ. Microbiol. 48: 1076-1083

Scavia, D., Laird, G. A., Fahnestiel, G. L. (1986). Production of planktonic bacteria in Lake Michigan. Limnol. Oceanogr 31: $612-626$

This article was presented by S. Y. Newell, Sapelo Island, Georgia, USA
Shoaf, W. T., Lium, B. W (1976). Improved extraction of chlorophyll $a$ and $b$ from aigae using dimethyl sulfoxide. Limnol. Oceanogr. 21: $926-928$

Stevenson, L. H., Millwood, C. E., Hebeler, B. H. (1974). Aerobic, heterotrophic bacterial populations in estuarine water and sediments. In: Colwell, R. R., Morita, R. Y. (eds.) Effect of the ocean environment on microbial activities. Univ. Park Press, Baltimore, p. 268-285

Vannucci, M. (1969). What is known about production potential of coastal lagoons. Lagunas Costeras, Un Simposio Mem. Simp. int. Lagunas. Costeras, UNAM-UNESCO, Universidad Nacional Autonoma de Mexico, Mexico City, p. $457-478$

Williams, R. B. (1972). Nutrient levels and phytoplankton productivity in the estuary. In: Chabrack, R. H. (ed.) Proceedings coastal marsh and estuary management symposium. Louisiana State Univ., Baton Rouge, p. 59-98.

Wright, R. T. (1984). Dynamic pools of DOC. In: Hobbie, J. E., Williams, P. L. (eds.) Heterotrophic activity in the sea. Proceedings of NATO SRI, Cascais, Portugal. Plenum Press, New York, p. 121-154

Wright, R. T, Coffin, R. B. (1984a). Ecological significance of biomass and activity measurements: factors affecting bacterioplankton density and productivity in salt marsh estuaries. In: Klug, M. L., Reddy, C. A. (eds.) Current perspectives in microbial ecology. Proc. 3rd int. Symp microbial ecology, Mich. State Univ. Am. Soc. Microbiol., Washington, D.C., p. 485-494

Wright, R. T., Coffin, R. B. (1984b). Measuring microzooplankton grazing on planktonic marine bacteria by its impact on bacterial production. Microbial Ecol. 10: $137-149$

Manuscript first received: April 22, 1992

Revised version accepted: July 29, 1992 